\title{
Efektifitas Dukungan Sosial Dokter kepada Orangtua dalam Tata Laksana Anak Asma
}

\author{
Fx. Wikan Indrarto, * Sutaryo, ** Djauhar Ismail** \\ *RS Bethesda, Yogyakarta \\ ** Bagian Ilmu Kesehatan Anak Fakultas Kedokteran Universitas Gadjah Mada/RS Dr. Sardjito, Yogyakarta
}

\begin{abstract}
Latar belakang. Salah satu keberhasilan tata laksana anak asma ditentukan oleh kebersamaan (partnership) yang terbentuk antara dokter dengan orangtua. Dalam kebersamaan tersebut, orangtua harus diberi dukungan sosial (social support) oleh dokter mencakup dukungan informasi, emosi, penghargaan (appraisal), dan alat bantu (instrumental) tentang asma.

Tujuan. Menilai efektifitas pemberian dukungan sosial dokter kepada orangtua dalam tata laksana anak asma.

Metode. Studi intervensi dengan desain kuasi eksperimental, dan interupted time-series design. Tempat penelitian di Klinik Anak RS Bethesda Yogyakarta selama bulan Juli-Desember 2008. Intervensi yang diteliti adalah pemberian dukungan sosial dokter di ruang praktek, kepada 82 orangtua dalam tata laksana anak asma. Pengaruh yang terjadi diukur, berdasarkan penilaian orangtua maupun dokter.

Hasil. Pemberian dukungan sosial dokter di ruang praktek, tidak berhubungan dengan perbaikan gejala klinis anak asma, berdasarkan penilaian orangtua (OR=1,01; IK 95\% 0,57-2,10) maupun penilaian dokter $(\mathrm{OR}=1,02$; IK 95\% 0,79-2,21) dan perbaikan kualitas hidup menurut orangtua $(\mathrm{OR}=1,03$; IK 95\% 0,46$3,12)$. Dukungan penghargaan kepada orangtua oleh dokter merupakan dukungan sosial yang paling memberikan kepuasan kepada orangtua $(p<0,05)$.

Kesimpulan. Pemberian dukungan sosial dokter tidak berhubungan dengan keberhasilan tata laksana anak asma. Kepuasan orangtua akan pemberian dukungan sosial dokter, terutama diperoleh dari jenis dukungan penghargaan. (Sari Pediatri 2009;11(4):305-10).
\end{abstract}

Kata kunci: kuasi eksperimental, dukungan sosial, anak asma

\section{Alamat korespondensi}

Dr. Fx. Wikan Indrarto, SpA : RS Bethesda Jl. Jend. Sudirman 70, Yogyakarta. Telp (0274) 586688, 081227280161, e-mail : fxwikan_ indrarto@yahoo.com
A sma merupakan penyakit pada anak yang semakin sering dijumpai di berbagai wilayah di seluruh dunia. ${ }^{1}$ Masalah tata laksana asma telah menjadi bahasan yang sangat menarik dewasa ini, sebab semakin banyak jumlah dan jenis obat asma yang tersedia, juga semakin meningkatnya penjualan obat asma, ternyata tidak mengurangi 
jumlah kasus asma. Bahkan di beberapa negara justru terjadi kenaikan prevalensi, morbiditas, dan mortalitas asma, sehingga program tata laksana asma perlu selalu ditinjau kembali. ${ }^{2}$ Dokter dan petugas medis seringkali hanya memeriksa pasiennya selama terjadi serangan akut asma dan tata laksana hanya berpusat pada gejala klinis dan pengendaliannya saja. Hal ini sejalan dengan tindakan dokter yang dominan pada aspek pengobatan farmakologis dan aspek biomedis asma, meskipun sebenarnya pasien dan keluarganya harus hidup bersama dan menanggung semua akibat asma dalam keseharian mereka. ${ }^{3}$ Selain itu, peran dokter dalam tata laksana asma anak seharusnya tidak boleh hanya sekedar menuliskan resep obat asma saja. ${ }^{4}$

Sudah dapat dibuktikan bahwa kurangnya pengetahuan tentang asma dan tata laksananya, berhubungan erat dengan peningkatan morbiditas dan mortalitasnya. ${ }^{5,6}$ Keberhasilan tata laksana asma pada anak, tidak hanya ditentukan oleh pemilihan dan penggunaan obat saja, tetapi ditentukan juga oleh adanya kebersamaan (partnership) yang terbentuk antara dokter dengan orangtuanya. Kebersamaan tersebut adalah pilar pertama dan terpenting dalam tata laksana asma. ${ }^{7}$ Dalam kebersamaan tersebut, orangtua pasien harus diberi dukungan sosial (social support) oleh dokter. Dukungan sosial didefinisikan sebagai sumber daya (afektif, kognitif dan alat bantu) yang diberikan melalui hubungan antar manusia untuk berinteraksi sosial. ${ }^{8}$ Dukungan sosial dokter mencakup bentuk dukungan informasi (edukasi), emosi (emotional), penghargaan (appraisal) dan alat bantu (instrumental) tentang asma secara menyeluruh. Sampai sekarang belum ada strategi rinci untuk terbentuknya kebersamaan antara orangtua dan dokter, termasuk bagaimana metode terbaik pemberian dukungan sosial kepada orangtua anak asma, yang mudah digunakan untuk para dokter di ruang praktek. Strategi pemberian dukungan sosial dokter kepada orangtua anak asma yang lengkap, sebaiknya berdasarkan sudut pandang orangtua (emic), karena asma tidak hanya memiliki dimensi medis, tetapi juga dimensi psikologis dan sosial. ${ }^{9}$

\section{Metode}

Penelitian berlokasi di Klinik Anak RS Bethesda Yogyakarta selama bulan Juli-Desember 2008. Untuk penelitian dengan perlakukan atau intervensi tata laksana yang baru (managerial innovation) dan keluaran yang diukur adalah efektifitas pelayanan kesehatan (effectiveness of health service delivery), penggabungan antara penelitian kualitatif dan kuantitatif merupakan metode terbaik yang dianjurkan. ${ }^{10}$ Penelitian dilakukan dalam 2 tahap.

1. Penelitian tahap pertama adalah penelitian kualitatif naturalistik untuk memahami fenomena pengetahuan, pengalaman, harapan dan sikap orangtua, tentang asma yang diderita oleh anaknya. Berdasarkan hal tersebut, kemudian disusun panduan pemberian dukungan sosial oleh dokter kepada orangtua anak asma. Tahap pertama telah dilaporkan terlebih dahulu.

2. Penelitian tahap kedua adalah penelitian kuantitatif yang merupakan studi intervensi dan bersifat kuasi eksperimental dengan rancang bangun interupted time-series design, untuk menilai efektifitas pemberian dukungan sosial dokter di atas. Tahap kedua dilaporkan dalam makalah ini.

Mengenai penelitian tahap kedua (kuantitatif), keterbatasan metode kuasi eksperimental adalah tidak dapat digunakan untuk menguji hipotesis kausal, sulit untuk proses ekstrapolasi atau generalability, tidak menggambarkan kebenaran sesungguhnya (true value), dan tidak dapat menyingkirkan perancu (confounder). ${ }^{11}$ Penelitian kuasi eksperimental menggunakan rancang bangun interrupted time-series design, sebab dilakukan beberapa kali pengukuran pada setiap subjek penelitian, yaitu sebelum dan setelah perlakuan atau intervensi, ${ }^{12}$ pemberian dukungan sosial oleh dokter kepada orangtua anak asma.

Data yang diperoleh dari penelitian tahap kedua (kuantitatif) dianalisis dengan analisis univariat, bivariat dan multivariat untuk mendapatkan rasio Odd (OR). Analisis kovarian dan stratifikasi digunakan untuk analisis tingkat kepuasan subjek terhadap perlakuan yang dialami. Secara statistik dianggap bermakna apabila $p<0,05$, telah dilakukan pemberian dukungan sosial oleh dokter kepada 82 orangtua anak asma.

Pasien yang diteliti adalah semua pasien baru balita yang menderita asma, yang datang ke lokasi penelitian. Kelompok balita dipilih dalam penelitian dengan pertimbangan,

- Insidensi asma pada anak semakin meningkat, terutama pada kelompok usia kurang dari 5 tahun. $^{13}$

- Gejala klinis asma pada anak kurang dari 5 tahun adalah batuk, bukan sesak nafas seperti asma pada dewasa. ${ }^{14}$ 
Fx. Wikan Indrarto dkk: Dukungan sosial dokter kepada orangtua dalam tata laksana asma anak

- Diagnosis asma pada anak kurang dari 5 tahun sulit, sebab pemeriksaan uji fungsi paru (spirometri) sebagai penguat diagnosis, belum dapat dikerjakan. ${ }^{15}$

- Overdiagnosis dan overtreatment dengan tuberkulosis paru lebih sering terjadi pada anak asma kurang dari 5 tahun. ${ }^{16}$

- Penolakan atau ketidakpercayaan orangtua kalau anaknya mengalami asma, lebih sering pada anak asma kurang dari 5 tahun. ${ }^{17}$

- Penelitian dan pengukuran variabel penelitian pada anak asma kurang dari 5 tahun, seharusnya melibatkan orangtua atau pengasuh anak. ${ }^{3}$

- Diagnosis dan tata laksana secara dini dengan terapi pengendali (inhalasi kortikosteroid), akan dapat mencegah terjadinya kerusakan saluran napas (remodelling) yang bersifat permanen, bila dilakukan pada anak asma kurang dari 5 tahun. ${ }^{18}$ Efektifitas tata laksana asma dinilai menggunakan 3 jenis kuesioner dan digunakan dalam penelitian ini, yaitu

1. Kuesioner dukungan sosial dokter yang diisi oleh orangtua.

2. Kuesioner keberhasilan tata laksana asma anak yang diisi oleh orangtua dan kuesioner kualitas hidup anak mengacu pada The Paediatric Asthma Quality of Life Questionnaire. ${ }^{19}$

3. Kuesioner derajad pengontrolan asma yang diisi oleh dokter yang diambil dari GINA ${ }^{7}$ dan PNAA. ${ }^{16}$

Proposal penelitian telah disetujui oleh Komisi Etik Penelitian Kedokteran dan Kesehatan Fakultas Kedokteran UGM Yogyakarta, dengan adanya Keterangan Kelaikan Etik (Ethical Clearance) telah diberikan dengan nomor KE/FK/534/EC, tertanggal 13 Oktober 2008, dan ditandatangani oleh Prof. Dr. dr. Soenarto Sastrowijoto, SpTHT(K) dan Prof. dr. Ngatidjan, M.Sc, SpFK(K). Persetujuan untuk mengikuti penelitian ini dimintakan secara lisan (verbal informed consent) kepada semua subjek penelitian, pada awal pertemuan.

Sesuai dengan rancang bangun interupted timeseries design, maka pengukuran keberhasilan tata laksana asma dilakukan pada 2 periode yang diselingi dengan perlakuan, yaitu

1. Sebelum perlakukan (before), dilakukan pada saat kunjungan pertama dan kedua di Klinik Anak. Perlakukan dilakukan pada kunjungan kedua, sehingga didapatkan dua data before.
2. Setelah perlakuan (after), dilakukan pada saat kontrol ulang di Klinik Anak yaitu pada kunjungan ketiga (1 minggu setelah perlakuan), keempat (1 bulan setelah perlakuan), dan kelima (3 bulan setelah perlakuan), sehingga didapatkan 3 data.

\section{Hasil}

Karakteristik subjek penelitian tertera pada Tabel 1 .

Tabel 1. Karakteristik subjek penelitian

\begin{tabular}{|c|c|c|}
\hline Karakteristik subjek & Keterangan & Jumlah \\
\hline \multirow{2}{*}{ Jenis kelamin anak } & Laki-laki & 51 \\
\hline & Perempuan & 31 \\
\hline \multirow[t]{2}{*}{ Umur anak (tahun) } & Kurang dari 3 & 54 \\
\hline & $3-5$ & 28 \\
\hline \multirow[t]{2}{*}{ Kunjungan anak ke UGD } & Pernah & 10 \\
\hline & Belum pernah & 72 \\
\hline \multirow[t]{2}{*}{ Rawat inap anak } & Pernah & 25 \\
\hline & Belum pernah & 57 \\
\hline \multirow[t]{2}{*}{ Derajad penyakit asma } & Episodik jarang & 36 \\
\hline & Episodik sering & 46 \\
\hline \multirow[t]{2}{*}{ Riwayat asma pada keluarga } & Ada & 61 \\
\hline & Tidak ada & 21 \\
\hline \multirow[t]{2}{*}{ Usia orangtua (tahun) } & $20-30$ & 50 \\
\hline & Lebih 30 & 32 \\
\hline \multirow[t]{2}{*}{ Pendidikan orangtua } & Rendah & 25 \\
\hline & Tinggi & 57 \\
\hline \multirow[t]{2}{*}{ Pekerjaan orangtua } & Bekerja & 55 \\
\hline & Tidak Bekerja & 27 \\
\hline \multirow[t]{2}{*}{ Sosial ekonomi } & Rendah & 32 \\
\hline & Tinggi & 50 \\
\hline \multirow[t]{2}{*}{ Tanggungan asuransi } & Ditanggung & 45 \\
\hline & Tidak ditanggung & 37 \\
\hline \multicolumn{2}{|c|}{ Jumlah subjek penelitian yang dianalisis } & 82 \\
\hline
\end{tabular}

Dari 82 orangtua anak asma yang diberi dukungan sosial oleh dokter di ruang praktek. Dari kuesioner yang diisi setelah keluar dari ruang praktek ('exit interview'), terdapat 51 orang merasakan memadai $(62,2 \%$ diberi kode dukungan sosial positif), sedangkan 31 orang lainnya tidak (37,8\% dan diberi kode dukungan sosial negatif).

Dari 51 orangtua yang merasakan adanya dukungan sosial dokter secara memadai, 48 orang $(94,1 \%)$ di antaranya menilai bahwa gejala klinis anaknya membaik setelah pemberian obat selama 1 minggu, 36 orang di antaranya $(70,6 \%)$ menilai bahwa asma anaknya dalam 
Fx. Wikan Indrarto dkk: Dukungan sosial dokter kepada orangtua dalam tata laksana asma anak

1 minggu setelah perlakuan membaik, 44 orang $(86,2 \%)$ dalam bulan pertama dan 40 orang $(78,4 \%)$ dalam 3 bulan kemudian. Sebaliknya, dari 31 orangtua yang tidak merasakan adanya dukungan sosial dokter, 29 orang $(93 \%)$ di antaranya menilai bahwa gejala klinis anaknya membaik setelah pemberian obat selama 1 minggu, jumlah yang sama 29 orang (93\%) menilai asma anaknya dalam 1 minggu setelah perlakuan membaik, 24 orang $(77,4 \%)$ dalam bulan pertama dan 30 orang $(96,7 \%)$ lainnya dalam 3 bulan kemudian.

Skor kualitas hidup anak asma menurut orangtua berkisar dari 23 (selalu merasakan dan amat sangat terganggu sekali karena gejala asma) sampai 161 (sama sekali tidak pernah merasakan gejala asma dan aktivitas anak dan keluarga tidak terganggu sama sekali).

Tidak ada perbedaan yang bermakna secara statistik pada semua kelompok. Dalam hal ini berarti perbaikan gejala klinis asma anak menurut dokter yang memeriksa, sudah terjadi pada saat kunjungan kedua, atau pada saat adanya perlakuan (before) sampai pada akhir penelitian (after). Selain itu, kelompok orangtua yang merasakan adanya dukungan sosial dokter secara memadai $(p=0,54)$, maupun pada kelompok yang sebaliknya $(p=0,21)$, sama-sama menilai adanya

Tabel 2. Keberhasilan tata laksana asma menurut orangtua $(n=82)$

\begin{tabular}{lccccc}
\hline & \multicolumn{5}{c}{ Jumlah anak dengan keberhasilan tata laksana asma } \\
\cline { 2 - 6 } Dukungan sosial & \multicolumn{3}{c}{ Sebelum perlakukan } & \multicolumn{3}{c}{ Setelah perlakuan } \\
\cline { 2 - 6 } & 1 minggu & 0 hari & 1 minggu & 1 bulan & 3 bulan \\
\hline Dukungan $(+) \mathrm{n}=51$ & 0 & 48 & 36 & 44 & 40 \\
Dukungan $(-) \mathrm{n}=31$ & 0 & 29 & 29 & 24 & 30 \\
\hline
\end{tabular}

Tabel 3. Skor rata-rata kualitas hidup anak asma menurut orangtua

\begin{tabular}{lccccc}
\hline & \multicolumn{5}{c}{ Rerata skor keberhasilan tata laksana asma } \\
\cline { 2 - 6 } Dukungan sosial & \multicolumn{4}{c}{ Sebelum perlakukan } & \multicolumn{3}{c}{ Setelah perlakuan } \\
\cline { 2 - 6 } & 1 minggu & 0 hari & 1 minggu & 1 bulan & 3 bulan \\
\hline Dukungan (+) & 44,2 & 122,6 & 131,3 & 129,2 & 130,9 \\
Dukungan (-) & 35,1 & 141,8 & 152,2 & 142,1 & 145,8 \\
\hline
\end{tabular}

Tabel 4. Hubungan dukungan sosial dokter dengan keberhasilan tata laksana asma menurut dokter $(\mathrm{n}=82)$

\begin{tabular}{lcccccc}
\hline & \multicolumn{2}{c}{ Keberhasilan tata laksana asma } & X2 & & & \\
\cline { 2 - 3 } Dukungan sosial dokter & $\begin{array}{c}\text { Tidak berhasil } \\
(\mathrm{n}=12)\end{array}$ & $\begin{array}{c}\text { Berhasil } \\
(\mathrm{n}=70)\end{array}$ & $(1)$ & $p$ & OR & IK 95\% \\
\hline Memadai $(\mathrm{n}=51)$ & 8 & 43 & 3,81 & 0,175 & 1,02 & $0,79-2,21$ \\
Tidak $(\mathrm{n}=31)$ & 4 & 26 & & & &
\end{tabular}

Tabel 5. Kepuasan orangtua ditinjau dari jenis dukungan sosial dokter

\begin{tabular}{lcccc}
\hline Jenis dukungan sosial & $\begin{array}{c}\text { Rerata skor pada } \\
\text { kunjungan pertama }\end{array}$ & $\begin{array}{c}\text { Rerata skor pada } \\
\text { kunjungan selanjutnya }\end{array}$ & $\begin{array}{c}\text { Uji statistik } \\
(\mathrm{Z})\end{array}$ & $p$ \\
\hline Informasi & 15,32 & 15,57 & 0,92 & NS $^{*}$ \\
Emosi & 15,82 & 15,13 & 1,23 & NS \\
Penghargaan & 14,85 & 19,01 & 3,95 & $<0,05$ \\
Alat bantu & 13,13 & 14,21 & 0,19 & NS \\
\hline
\end{tabular}

${ }^{*} \mathrm{NS}=$ not signifance 
Fx. Wikan Indrarto dkk: Dukungan sosial dokter kepada orangtua dalam tata laksana asma anak

perbaikan gejala klinis asma. Pemberian dukungan sosial dokter di ruang praktek yang menggunakan buku panduan, tidak berhubungan dengan perbaikan gejala klinis anak asma, berdasarkan penilaian dokter dengan $p=0,17$ dan $\mathrm{OR}=1,02(0,79-2,21)$.

Kepuasan terhadap masing-masing jenis dukungan sosial tertera pada Tabel 5. Dukungan informasi (edukasi), dukungan emosi dan dukungan alat bantu (instrumental) tidak didapatkan perbedaan antara kunjungan pertama dan kunjungan selanjutnya. Menunjukkan bahwa jenis dukungan sosial tersebut telah memenuhi harapan orangtua anak asma. Dukungan penghargaan (appraisal) pada kunjungan pertama lebih rendah dibandingkan dengan kunjungan selanjutnya dan perbedaan ini bermakna secara statistik $(p<0,05)$. Berarti bahwa dukungan penghargaan yang diberikan dokter secara berulang-ulang pada kunjungan kedua dan selanjutnya, lebih memberikan kepuasan kepada orangtua anak asma.

Hasil analisis kovariant pada Tabel 6, kelima jenis efek utama secara statistik tidak bermakna $(p>0,05)$. Berarti faktor keluarga yang meliputi usia orangtua, pekerjaan, pendidikan, tingkat sosial ekonomi, riwayat asma pada keluarga dan adanya tanggungan asuransi untuk anak, secara bersama-sama tidak mempengaruhi kepuasan total pemberian dukungan penghargaan (appraisal) oleh dokter kepada orangtua. Dengan kata lain, kepuasan orangtua terhadap pemberian dukungan sosial dokter, yaitu jenis dukungan penghargaan (appraisal), tidak terkait dengan kelima faktor keluarga di atas. Hasil interaksi dua jalan secara bersama-sama tidak mempengaruhi kepuasan orangtua, sehingga tidak dilakukan stratifikasi.

Tabel 6. Pengaruh beberapa faktor dengan kepuasan orangtua terhadap pemberian dukungan penghargaan (appraisal) oleh dokter

\begin{tabular}{lccc}
\hline Faktor keluarga & $\mathrm{F}$ & $\mathrm{db}$ & $p$ \\
\hline Pekerjaan & 0,721 & 9 & $\mathrm{NS}$ \\
Pendidikan & 0,835 & 1 & $\mathrm{NS}$ \\
Tingkat sosial ekonomi & 0,171 & 1 & $\mathrm{NS}$ \\
Riwayat asma pada keluarga & 0,552 & 2 & $\mathrm{NS}$ \\
Asuransi kesehatan & 0,367 & 2 & $\mathrm{NS}$ \\
Analisis kovariat & 0,278 & 2 & $\mathrm{NS}$ \\
Usia orangtua & 0,065 & 1 & $\mathrm{NS}$ \\
\hline
\end{tabular}

Uji statistik dengan analisis kovariansi 5 jalan dengan satu kovariabel (perhitungan kovariat bersamaan dengan faktor dan efek utama). NS=tidak bermakna secara statistik $(p>0,05)$

\section{Diskusi}

Didapatkan perbaikan gejala klinis asma pada sebagian besar anak, baik menurut dokter yang memeriksa maupun menurut orangtua, yang telah terjadi pada saat kunjungan ke-2, atau 1 minggu setelah pemberian obat asma pada kunjungan pertama. Berarti bahwa diagnosis asma dapat ditegakkan. Menurut pedoman dari UKK Pulmonologi IDAI (2004), ${ }^{16}$ adanya respons yang baik terhadap obat bronkodilator dan steroid sistemik selama 5 hari dan dengan menyingkirkan penyakit lain, maka diagnosis asma menjadi lebih definitif. Terjadinya pengendalian gejala klinis asma pada sebagian besar anak asma dalam penelitian kami, yaitu sejak kunjungan ke-2 sampai terakhir, sangat terkait dengan derajat penyakit asma, yaitu sebagian besar merupakan asma episodik jarang. Juga terlihat pada hasil analisis multivariat beberapa faktor sebagai variabel pengganggu, yaitu faktor anak (usia anak, kunjungan IGD karena asma, rawat inap karena asma dan derajad penyakit asma) dan faktor keluarga (usia orangtua, pekerjaan, pendidikan, tingkat sosial ekonomi, riwayat asma pada keluarga dan adanya asuransi kesehatan) yang tidak berhubungan dengan keberhasilan tata laksana asma anak, yaitu tidak ada satupun yang bermakna secara statistik $(p>0,05)$.

Kepuasan orangtua terhadap dukungan sosial yang diberikan dokter, terlihat hanya pada pemberian dukungan penghargaan (appraisal). Dukungan pengharaan (appraisal) merupakan dukungan sosial yang paling diperlukan oleh orangtua, seperti yang didapatkan Hanifah ${ }^{20}$, Cohen ${ }^{21}$ dan Gallant. ${ }^{22}$ Gallant menunjukkan bahwa efek utama dukungan sosial adalah pada penerimaan keadaan (adherence), karena adanya dukungan penghargaan (appraisal) tersebut, bukan karena kemampuannya melindungi tubuh terhadap stresor fisik. ${ }^{22}$ Cohen ${ }^{21}$ menunjukkan bahwa hubungan yang efektif antara dokter, orangtua dan pasien merupakan inti keberhasilan tata laksana asma. Peningkatan ketrampilan dokter dalam memberikan dukungan sosial kepada orangtua, terutama jenis dukungan penghargaan (appraisal) perlu selalu diwujudkan untuk meningkatkan efektifitas hubungan keduanya. Hal yang cukup sederhana adalah mengucapkan 'terima kasih' kepada orangtua anak asma yang datang di ruang praktek, selayaknya dijadikan kebiasaan, bahkan mendahului ucapan yang sama yang dikatakan orangtua. Hal tersebut merupakan perubahan yang cukup mencolok dalam paradigma hubungan antara dokter dengan pasien dan keluarganya. 
Fx. Wikan Indrarto dkk: Dukungan sosial dokter kepada orangtua dalam tata laksana asma anak

\section{Kesimpulan}

Pemberian dukungan sosial dokter yang menggunakan buku panduan tersebut, tidak berhubungan dengan keberhasilan tata laksana anak asma. Kepuasan orang tua akan pemberian dukungan sosial dokter, diperoleh dari jenis dukungan penghargaan (appraisal).

\section{Daftar Pustaka}

1. Hassan MR, Kabir AL, Mahmud AM, Rahman F, Hossain MA, Bennoor KS, dkk. "Self-reported asthma symptoms in children and adults of Bangladesh: findings of the National Asthma Prevalence Study", Inter J Epidemiol 2002;31:483-8.

2. Sungkar S. Aspek Biomedis tungau debu rumah. 2004. Didapat dari: http://www.pdpersi.co.id/?show=detail newserkode $=8780$ tbl $=$ kesling.

3. Barton C, Sulaiman N, Clarke D, dan Abramson M. Experiences of Australian parents caring for children with asthma: it gets easer. Chronic Illness 2005;1:303-14.

4. Chung KF. Clinicians' guide to asthma. Arnold, a member of the Hodder Headline Group, 338 Euston Road, London NW1 3BH Didapat dari: http://www. arnoldpublishers.com

5. Lenfant $\mathrm{C}$ and Khaltaev N. Global initiative for asthma. NHLBI/WHO Workshop Report 2002 Miles MB and Huberman AM. 1992. Analisis data kualitatif; Penerjemah: Tjetjep Rohendi Rohidi, Jakarta: Penerbit Universitas Indonesia (UIPress), 2002.

6. Sly M. Asthma. Dalam: Behrman RE, Kliegman RM, Arvin AM, penyunting. Nelson Textbook of Pediatric. Edisi ke 15, Philadelphia: Saunders; 1996.h. 628-40.

7. Global initiative for asthma (GINA). "Global strategy for asthma management and prevention ". NIH publication, Washington: National Institutes of Health, National Heart, Lung and Blood Institute; 2006.

8. Cohen S, Syme SL, penyunting. Social support and health, Orlando Florida: Academic press inc;1985.h.19-166.

9. Prokop CK, Bradley LA, Burish TG, Anderson KO, Fox JE. Health psychology, clinical methods and research.
New York: McMillan Publishing Co; 1991.h.314-29.

10. Gray JAM. Evidence-based Healthcare. Edisi ke-2. Edinburg: Churchill Livingstone;2001.h.121-61.

11. Gribbons A, Barry G, Herman K, Joan G. "True and quasi-experimental designs". Practical assessment, research \& evaluation, Chicago: Rand McNally College Pub. Co, 1997. Didapat dari: http://PAREonline.net/ getvn.asp?

12. Campbell DT, Stanley JC. "Experimental and quasiexperimental designs for research”. Chicago: Rand McNally College Pub Co; 1966.

13. Bray MA, Kehle TJ, Grigerick SE, Loftus S, Nicholson H. Children with asthma: Assessment and treatment in school settings, psychology in the schools 2008;45 Didapat dari: www.interscience.wiley.com.

14. Strauss A, Corbin J. Basic of qualitative research. London: Sage Publication; 1990.h.17-186.

15. Nystad D. 2003. Didapat dari: www.cat.inist,frl?aModele $=$ afficheNecpsidt.

16. Holt EW, Tan J, Hosgood D. "The impact of spirometry on pediatric asthma diagnosis and treatment". Journal of Asthma 2006;43: 489-93.

17. UKK Pulmonologi PP-IDAI. Pedoman nasional asma anak (PNAA), Jakarta, 2004.

18. Wolf JM, Miller GE, Chen. Parent psychological states predict changes in inflammatory markers in children with asthma and healthy children, brain, behavior, and immunity 2007;22:433-41.

19. Eid NS. Update on national asthma education and prevention program pediatric asthma treatment recommendations. Clin Peadiatr 2004; 43: 793-802.

20. Juniper EF, Guyatt GH, Feeny DH, Ferrie PJ, Griffith LE, Townsend M. "Measuring quality of life in children with asthma”. Quality of Life Research 1996;5:35-46.

21. Hanifah. 2003. dalam http://72.14.235.104/digilib.itb. ac.id/2003-hanifah-8770- keluarga\%26q\%3DSosial+duk ungan+sosialor $h l=i d \& c t=8$

22. Cohen SY, Wamboldt FS. The parent-physician relationship in pediatric asthma care. Journal of Pediatric Psychology 2000;25:69-77.

23. Gallant PM. The influence of social support on chronic illness self-management: a review and directions for research. Health Educ Behav 2003;30:170-95. 